\title{
PREGLED KRITERIJA ZA IZBOR GEOTEKSTILA ZA FILTAR
}

\author{
Nada Perić \\ Sveučilište Josipa Jurja Strossmayera u Osijeku, Građevinski fakultet Osijek, student \\ Mensur Mulabdić \\ Sveučilište Josipa Jurja Strossmayera u Osijeku, Građevinski fakultet Osijek, redoviti profesor
}

Sažetak: U radu se obrađuje primjena geotekstila za filtre i drenaže u geotehničkim i hidrotehničkim zahvatima. Analizirani su mehanizmi važni za dobro funkcioniranje geotekstila kao filtra koji se odnose na začepljenje, blokiranje i smanjenje pornog tlaka u zoni filtra. Na temelju raspoložive literature napravljen je pregled kriterija za izbor geotekstila kao filtra, u što su uvršteni i važeći nacionalni pravilnici. Prikazan je primjer definiranja kriterija za izbor geotekstila za filtar za ceste i za odlagalište otpada.

Ključne riječi: filtar, geotekstil, tlo, kriteriji, primjena

\section{A REVIEW OF CRITERIA FOR GEOTEXTILE FILTER}

Abstract: In this paper analysis of application of geotextiles for filters and drainage in geotechnical and hydrotechnical works is presented. The mechanisms important for functioning of geotextiles as filters related to clogging, blocking, and reduction of pore pressure in the filter-zone, are analyzed. Important criteria for selection of geotextiles as filters, based on available literature and relevant national guidelines, are summarized and compared. Examples of selection criteria for geotextile filter on highways and landfills are presented.

Key words: filter, geotextile, criteria, application 


\section{Uvod}

Mnoge geotehničke i hidrotehničke građevine zahtijevaju postojanje i izgradnju slojeva / zona koji će osigurati protjecanje vode i spriječiti iznošenje čestica iz određenog dijela građevine. Time će se spriječiti i nastanak prekomjernog porasta pornog tlaka koji može izazvati pad čvrstoće i, posljedično, nestabilnost dijela ili čitave građevine. Taj zadatak obavljaju filtri.

Filtar je sloj ili više slojeva propusnog materijala, projektiran i ugrađen za dreniranje vode bez iznošenja sitnih čestica tla. Postavlja se između dva sloja bitno različite propusnosti i mora zadovoljiti dva uvjeta: a) da je dovoljno propustan kako bi voda u njemu tekla uz znatno smanjen gradijent i b) da voda kroz pore ne može iznositi sitne čestice iz zaštićenog materijala. Uvjet za uspješno djelovanje filtra jest prilagođenost materijalu koji treba štititi. Svrha ovoga rada je opisati način funkcioniranja i način primjene geotekstila za izgradnju filtra, sukladno današnjim saznanjima i praksi u svijetu i u Hrvatskoj. U radu su predstavljeni zahvati / objekti u kojima se uspješno koriste geotekstili kao filtri, prikazan je mehanizam djelovanja filtra za prirodne materijale i za geotekstil, dan je pregled kriterija za izbor geotekstila za filtar prema hrvatskim pravilnicima i prema mjerodavnoj literaturi. Kroz primjer zahtjeva za izbor geotekstila za filtar u prometnicama i u odlagalištima otpada, ilustrirana je primjena prezentiranih kriterija.

\section{Općenito o primjeni geosintetika za filtre}

Klasični filtri u građevinarstvu se izvode od jednog ili više slojeva prirodnih materijala kao što su pijesak i šljunak. U posljednje vrijeme sve veću primjenu nalaze sintetički materijali, tzv. geosintetici. Kada voda dospije na geosintetik i počne teći u njegovoj ravnini, geosintetik postaje dren. Zbog toga se zahtijeva određena propusnost ili potencijal otjecanja kroz geosintetik, odnosno transmisivnost. Geosintetici koji imaju sposobnost filtriranja (slika 1) su geotekstili i neki geokompoziti (u kojima se nalazi geotekstil).

Geotekstil je planaran, propustan, polimerni (sintetički ili prirodni) tekstilni materijal, koji može biti netkani, pleteni ili tkani, koji se koristi u dodiru s tlom i/ili drugim materijalima u geotehničkim i ostalim građevinskim zahvatima [1]. Razlozi za brzo prihvaćanje i korištenje geosintetika u građevinarstvu su njihova djelotvornost u ispunjavanju funkcija, kontrolirani uvjeti proizvodnje s kontroliranim svojstvima proizvoda, uspješnost u zamjeni prirodnih materijala, prihvatljiva cijena, brzo postavljanje, velika mogućnost varijantnih projektnih rješenja te često nedostatak prirodnih materijala za izvedbu filtra. Osnovni polimeri iz kojih se izrađuju geotekstili su polipropilen (92\%) - poliester (5\%) - polietilen (2\%), - poliamid (najlon, $1 \%$ ).

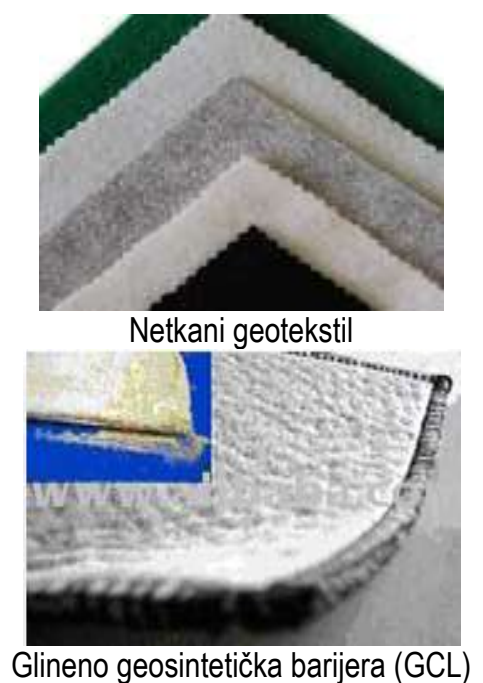

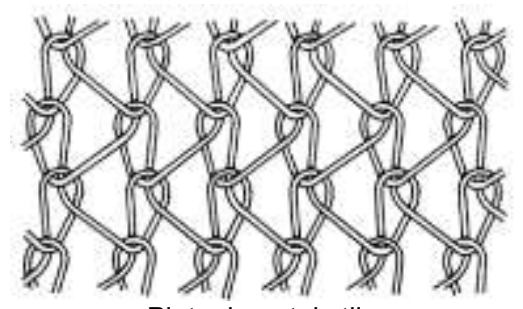

Pleteni geotekstil

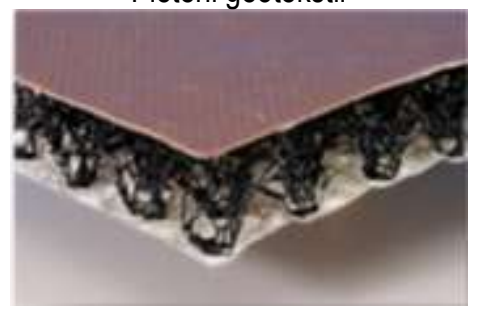

Geopletivo s geotekstilom

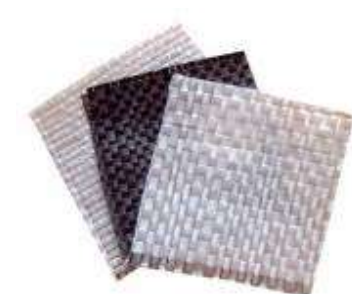

Tkani geotekstil

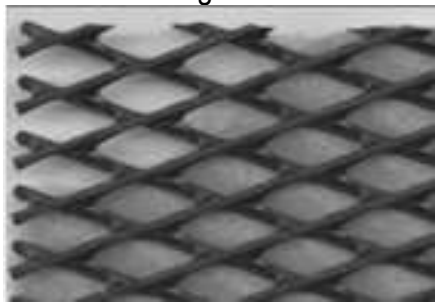

Georešetka s geotekstilom

Slika 1 - Različite vrste geotekstila po načinu proizvodnje (gore) i različiti geosintetici (geokompoziti) koji sadrže geotekstil (dolje) [2] 
Filtri u građevinama smanjuju porne tlakove te djelovanje vode na konstrukciju. Tipične građevine u kojima su filtri neophodni su: brane, nasipi, potporne konstrukcije, nasipi prometnica, odlagališta otpada, zaštite obala i slično. Na slici 2 prikazana je primjena geotekstila kao drena ili filtra u različitim konstrukcijama: za potporni zid, gdje je važno smanjiti tlakove vode na zid, za prometnice, gdje se odvodnjom umanjuje opasnost od srmzavanja i umanjenja nosivosti kolničke konstrukcije, te za ubrzanje konsolidacije u tlu ispod nasipa, gdje se vertikalnim prefabriciranim drenovima ubrzava slijeganje temeljnog tla nasipa.

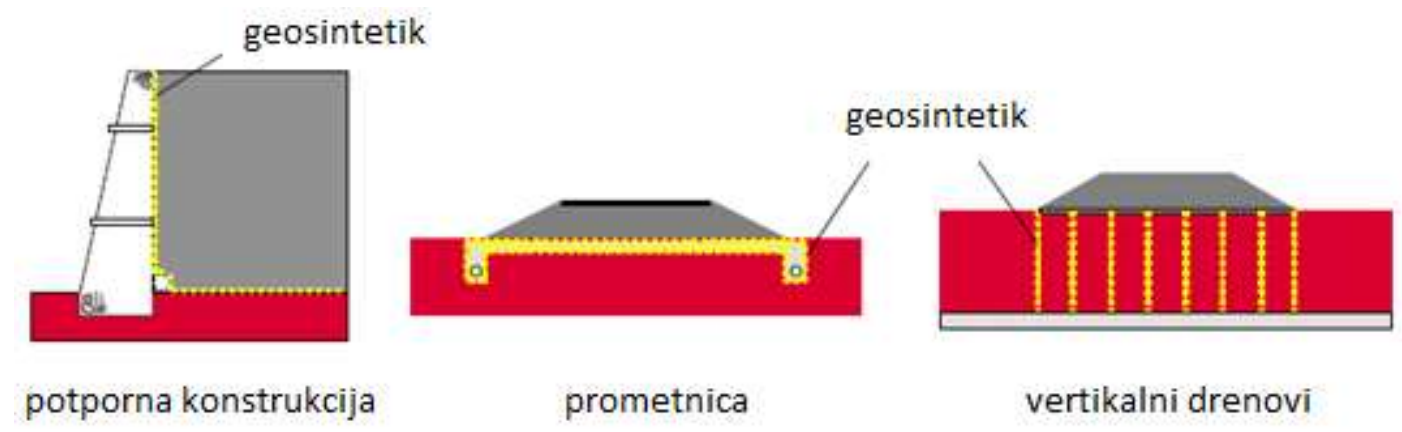

\section{Slika 2 - Prikaz različitih primjena geotekstila kao drena i filtera [3]}

U odlagalištima otpada potrebno je osigurati dobro dreniranje filtrata (kojeg možemo nazvati iscjedna voda) U cijelom sustavu za drenažu, u temeljnom brtvenom sloju (oko cijevi, na kontaktu drena i otpada) mora se filtrirati filtrat, a za to se najčešće koriste geotekstili, ako se ne koristi pijesak (slika 3).

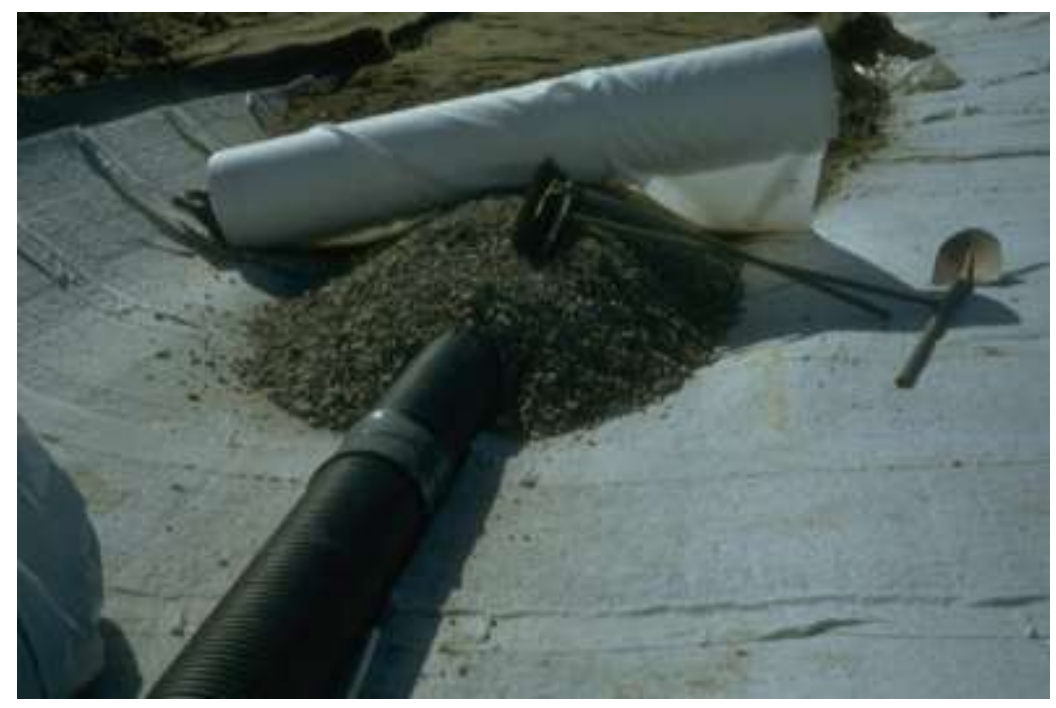

\section{Slika 3 - Drenažne cijevi u temeljnom drenažnom sustavu odlagališta otpada obložene su šljunkom oko kojega se postavlja geotekstil za filtriranje filtrata [3]}

Nasute brane moraju imati filtre. Grade se kao privremeni ili trajni objekti kojima se pregrađuje riječno korito radi ostvarenja akumulacije za energetske potrebe, navodnjavanje ili reguliranje protoka. Nasute brane izvode se od tla, kao homogeni ili zonirani objekti prilagođeni lokalnim uvjetima.

Homogene nasute brane sastoje se od jedne vrste materijala, koji mora biti dovoljno malo propustan da procjeđivanje kroz branu ostane u tehnički prihvatljivim granicama. Sasvim homogena brana ne može biti trajno stabilna pa mora imati barem neke drenove. Oni mogu biti izvedeni kao plošni dren ispod nizvodnog dijela brane, kao propusna stopa u nizvodnom pokosu brane ili kao vertikalni dren u sredini presjeka brane, spojen sa stopom nizvodnog pokosa brane [4] (slika 4). 
Drenovi mogu biti izvedeni od geokompozita - geodrena. Funkciju filtracije i dreniranja ima geodren, to je geokompozit sastavljen od geomreže i geotekstila koji može biti s jedne ili obje strane geomreže (vidi sliku 1). Predgotovljeni vertikalni dren (PVD) ima dva elementa: nosiva rebrasta traka u unutrašnjosti geotekstila i geotekstilna košuljica koja ju obavija. Geotekstil omogućuje filtraciju, a traka osigurava razmak geotekstila i krutost pri utiskivanju. Ovi drenovi su debljine do $5 \mathrm{~mm}$ i širine do $100 \mathrm{~mm}$, utiskuju se posebnim priborom pomoću stroja sličnom bušaćem stroju: stroj povlači dren s koluta, na dnu trake koja se prvo utiskuje postavi se vodilica - metalna trokutasta pločica koju stroj zahvati pomoću specijalne vilice i utiskuje ju u tlo, te ona ostaje u tlu, a dren se iznad površine prereže (tridesetak centimetara iznad tla).

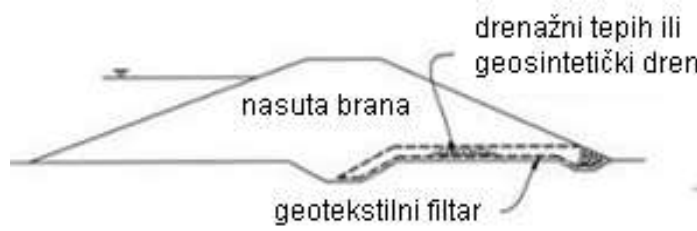

Drenažn tepih

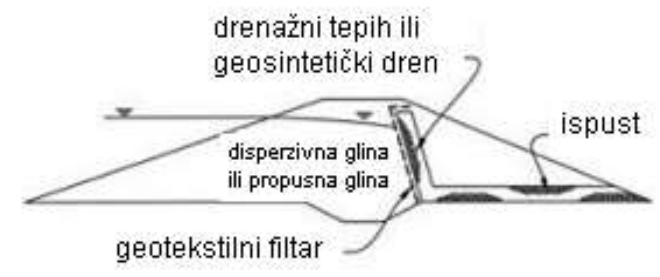

Dren u obliku dimnjaka

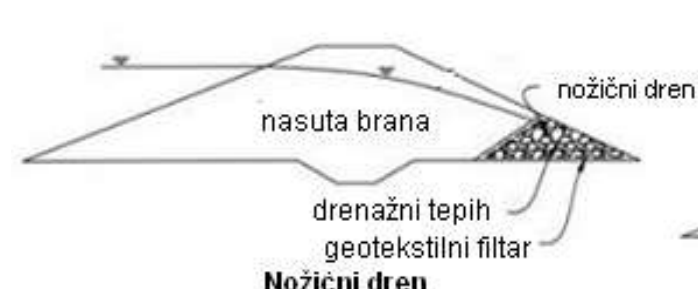

Nožični dren

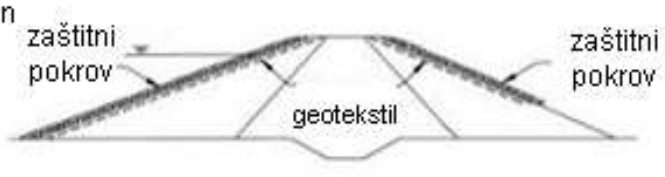

Obložni filtar

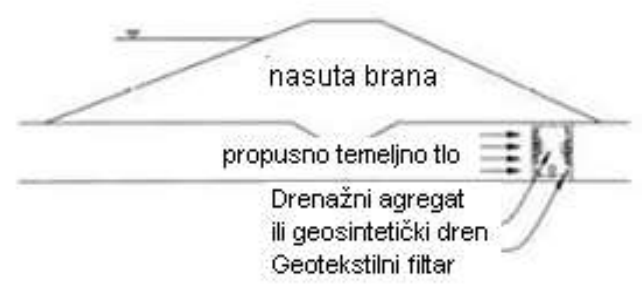

Dren kao rov

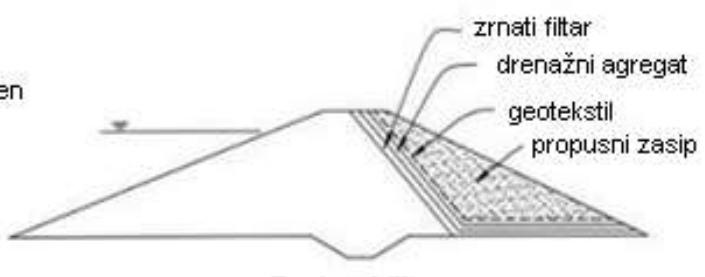

Zonirani filtar

\section{Slika 4 - Različiti položaji filtra u nasutim branama [5]}

Ovi drenovi služe za ubrzanje konsolidacije tla (npr. tlo ispod nasipa prometnica). Njihov razmak ovisi o svojstvima tla i željenoj brzini konsolidacije, ali se uobičajeno kreće od 60 do $100 \mathrm{~cm}$ (slika 5). Kao i kod izbora geotekstilnog filtra i ovdje se mora voditi računa o filtarskim pravilima za dano tlo.
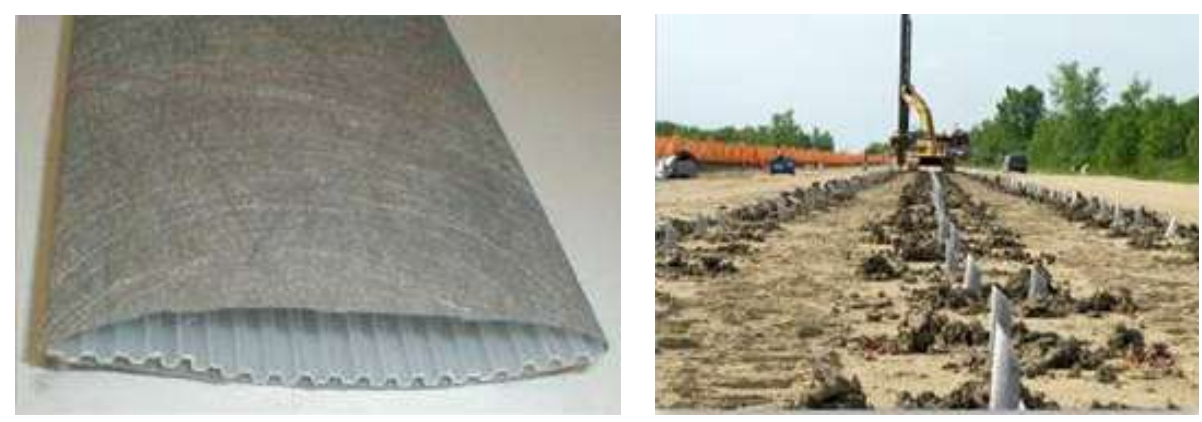

Slika 5 - Predgotovljeni vertikalni dren -PVD (lijevo) i postavljanje na terenu utiskivanjem specijalnim strojem i priborom (desno) [2] 
Geodren mora imati dovoljnu robusnost da bi tijekom postavljanja i vijeka korištenja građevine ostao funkcionalan, geomreža mora biti otporna na predviđena opterećenja da ne bi onemogućavala protok, mora imati kemijsku postojanost, a za geotekstile vrijede ista pravila kao i kad su samostalni dio građevine. $U$ narednim poglavljima prikazat će se mehanizmi (fizikalni i hidraulički) o kojima ovisi djelotvornost i trajnost filtra, bilo od tla, bilo od geotekstila.

\section{Mehanizam djelovanja filtra}

Glavni zadatak filtra je spriječiti ispiranje čestica osnovnog tla i omogućiti što slobodnije kretanje tekućine kroz njega. Pritom se ne zadržavaju sve čestice, jedan manji dio čestica biva pronesen vodom kroz pore filtra. U tlu istraživači razlikuju čestice tla koje tvore skelet tla (nosivi dio tla, međusobno u kontaktu) od ostalih čestica, koje su sitnije i nisu u kontinuiranom kontaktu $[6,7,8]$. Filtar treba osigurati stabilnost čestica koje tvore skelet.

Kod slabo graduiranih materijala skelet nije dobro formiran pa postoji mogućnost da se ispere i dio čestica skeleta, tada govorimo o internoj nestabilnosti tla. Drugim riječima, neke male čestice tla smiju se pomaknuti do filtra i/li biti iznesene kroz filtar i to kretanje ne utječe na promjenu i stabilnost strukture (skeleta) tla $[6,7,8]$. Filtar može biti blokiran česticama koje se gomilaju na njegovoj površini ili začepljen česticama koje ispune njegov porozitet (slika 6), i tada može izgubiti svoju funkciju.

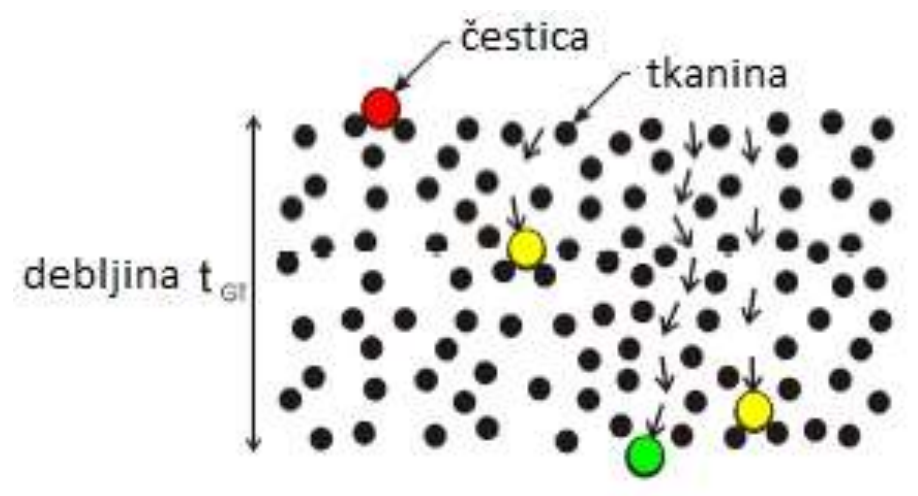

Slika 6 - Načini prolaska čestica kroz geotekstil - neke čestice ostaju na površini geotekstila, neke se zaustavljaju unutar geotekstila, a neke prolaze kroz geotekstil [9]

Nekoliko mehanizama karakterizira djelovanje filtra u tlu:

a) stvaranje "mostova” čestica u osnovnom tlu

b) erozija osnovnog materijala

c) blokiranje pora filtra

d) začepljenje filtra.

U slučaju interno stabilnog tla, postoje čestice tla koje tvore kontinuiranu strukturu tla, odnosno tvore tzv. skelet tla $[6,8]$. Oko i unutar takvog skeleta tla raspoređene su čestice tla koje su manje od čestica koje tvore skelet; te manje čestice okružuju još manje čestice tla i tako se proces nastavlja [8]. Pri tečenju vode prema filtru, u osnovnom tlu (uzvodno od filtra) pojavljuje se prvo manjak sitnijih čestica koje je isprala voda, ali je ostao skelet, a iza toga skeleta je struktura zapunjena česticama različite veličine, stabiliziranih skeletom. Govori se 0 formiranim „mostovima čestica" koji djeluju kao interni filtar u tlu. Stoga, ako filtar ima takve otvore da zadrže skelet tla, tlo će iza filtra ostati stabilno (slika 7). 


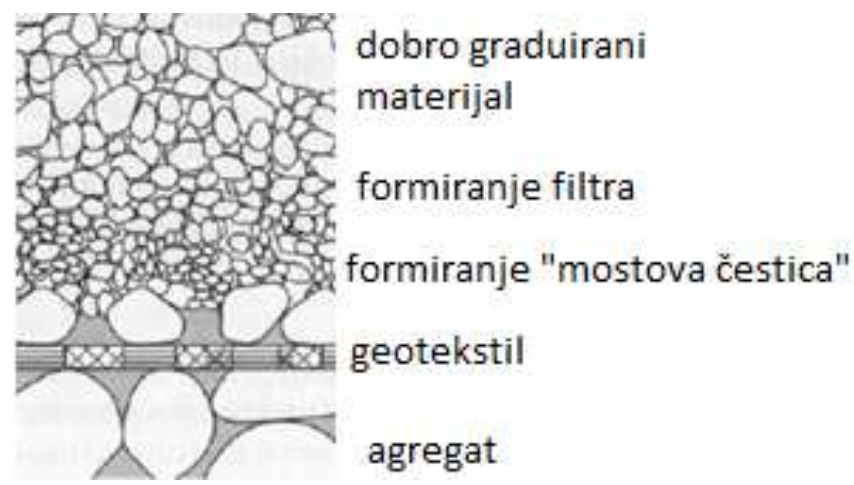

\section{Slika 7 - Prikaz stvaranja internog filtra u tlu [9]}

Erozija osnovnog tla događa se ako su pore geotekstila prevelike i ne sprječavaju iznošenje čestica osnovnog skeleta tla (nije zadovoljen kriterij zadržanja). To može izazvati značajne promjene volumena u tlu, što može proizvesti deformacije koje mogu biti nedopuštene i štetne za kontrukciju [8].

Blokiranje geotekstilnog filtra nastaje na površini geotekstila, kada je filtar u kontaktu s interno nestabilnim tlom. Ako hidraulički tok odnosi čestice osnovnog skeleta tla, a veće su od pora geotekstila, ove čestice će se nakupiti na sučelju geotekstil - tlo i formirati zonu niske propusnosti [8]. U tom slučaju tlo ima veću propusnost od geotekstila, pa smanjeno otjecanje vode kroz geotekstil može izazvati povećane porne tlakove koji i na tlo i na geotekstil djeluju kao opterećenje.

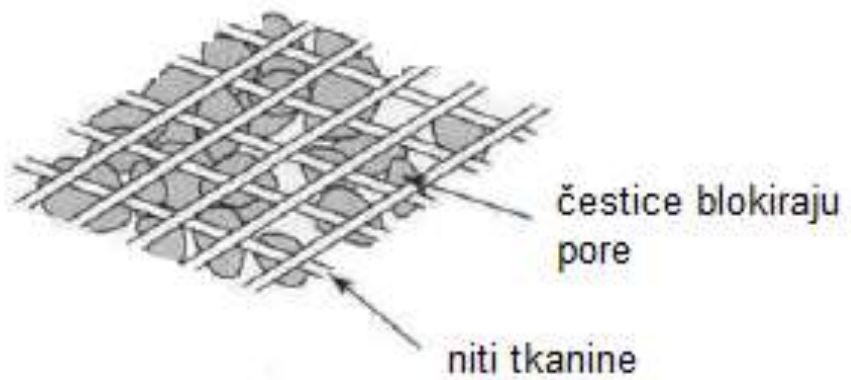

\section{Slika 8 - Blokiranje pora geotekstila [9]}

Začepljenje filtra događa se kada se čestice osnovnog tla nakupljaju u porama filtra (slika 8), što rezultira smanjenjem propusnosti. Dva tipa mehanizma omogućuju nakupljanje materijala u porama geotekstila: nakupljanje čestica tla i nakupljanje biološkog ili kemijskog materijala - formiranjem mreža i gnijezda nastalih aktivnostima bakterija i/ili taloženjem i izlučivanjem [8]. Ovaj fenomen rezultira smanjenjem propusnosti te povećanjem pornog tlaka u osnovnom tlu (slika 9).

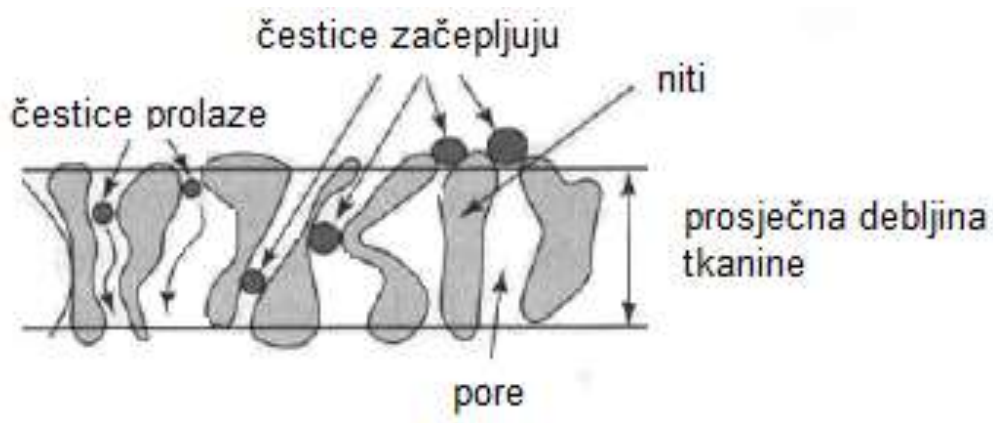

Slika 9 - Začepljenje pora geotekstila [9] 
Prisutnost filtra poremećuje tok vode kroz tlo uzvodno od filtra čak i kad on uspješno djeluje. Odabrani filtar mora biti takav da je poremećaj mali i prihvatljiv. Poremećaj može utjecati na porni tlak i protok [6], kako je to prikazano na slikama $10 \mathrm{i} 11$. Prisutnost filtra potencijalno povećava porni tlak vode u tlu, uzvodno od filtra. Visoki porni tlak može imati određene štetne učinke. Odabrani filtar mora biti takav da povećanje pornog tlaka bude što je manje moguće, a idealno bi bilo da povećanja pornog tlaka nema. Slika 11 (lijevo) uspoređuje krivulju pornog tlaka kao funkciju dubine za slučaj kada ne postoji filtar, sa slučajem kada je on neučinkovit i tada postoji značajno povećanje pornog tlaka. To je općenito tako, međutim, povećanjem koeficijenta propusnosti filtra $\left(k_{F}\right)$ postiže se smanjenje pornog tlaka dok se ne postigne idealna situacija da uopće nema povećanja pornog tlaka, kako je prikazano na slici 11 (desno).

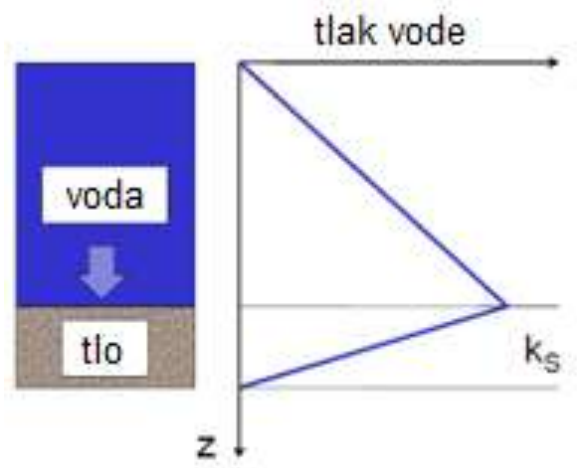

Slika 10 - Krivulja pornog tlaka u slučaju kada u tlu nema filtra; $k_{s}=$ propusnot tla [6]

Povećanja pornog tlaka neće biti ako se postigne da je odnos koeficijenta propusnosti filtra $\mathrm{k}_{\mathrm{F}} \mathrm{i}$ koeficijenta

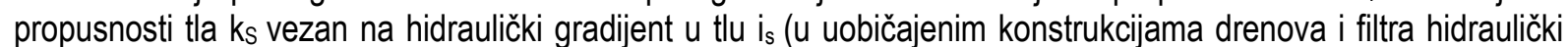
gradijent ima vrijednost oko 1-2):

gdje je:

$$
\mathrm{k}_{\mathrm{F}} \geq \mathrm{i}_{\mathrm{S}} \mathrm{k}_{\mathrm{s}}
$$

$\mathrm{i}_{\mathrm{s}} \quad$ hidraulički gradijent u tlu (gubitak potencijala na nekoj udaljenosti).
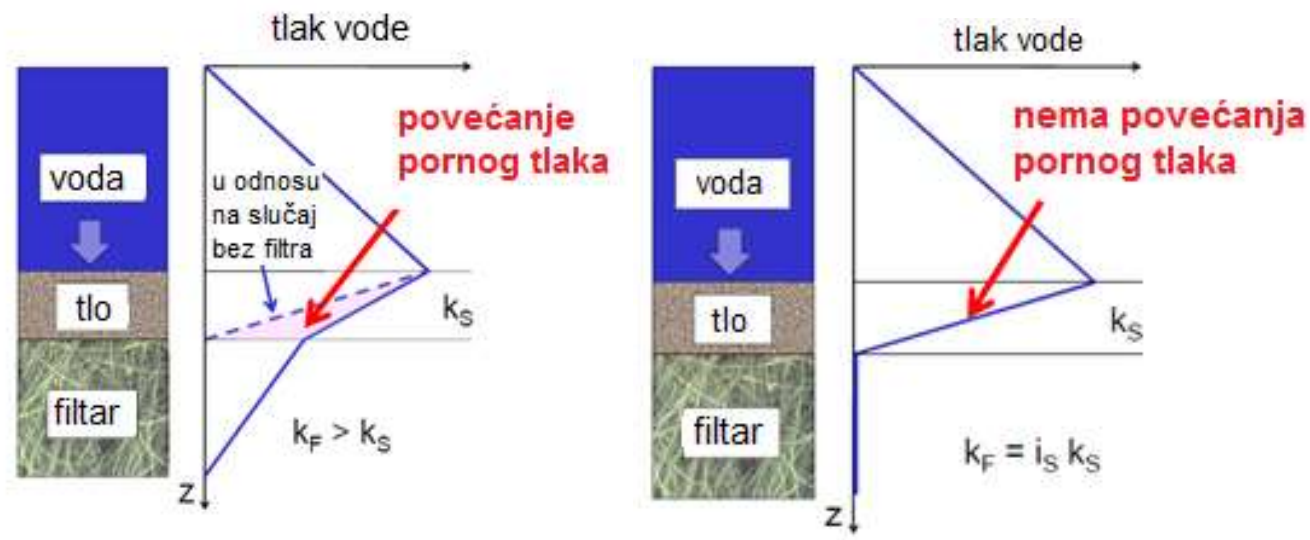

\section{Slika 11 - Povećanje pornog tlaka zbog nedovoljne propusnosti filtra (lijevo) i nepostojanje porasta pornog tlaka kada je propusnost filtra dovoljna (desno) [6]}

Klasična filtarska pravila, široko rasprostranjena u inženjerskoj praksi kada se koriste prirodni materijali za filtar, potiču još od Terzaghija i odnose se na zadržavanje čestica tla (najzahtjevniji dio razvoja kriterija za filtre) i na propusnost filtra. Može se reći kako je, zapravo, kriterij zadržanja najvažniji aspekt funkcije filtracije [6]. 
Klasični Terzaghijev kriterij zadržanja glasi:

$$
d_{15 F} \leq 4 i l i 5 d_{85 s}
$$

gdje je:

$d_{15 F} \quad$ promjer zrna u filtru ispod kojeg je $15 \%$ mase filtra

$d_{85 s} \quad$ promjer zrna u tlu ispod kojeg je $85 \%$ mase tla ( odnosi se na tlo koje se štiti).

Terzaghijev kriterij propusnosti traži da je zadovoljeno:

$$
d_{15 F} \geq 4 i l i 5 d_{15 s}
$$

gdje je:

$d_{15 s}$ promjer zrna u tlu ispod kojeg je $15 \%$ mase tla (odnosi se na tlo koje se štiti).

Jednadžba (2) znači da $d_{15}$ filtra ne smije biti prevelik. Razlika između faktora 4 i 5 upotrijebljena u jednadžbi nije značajna. Treba primijetiti da su oba Terzaghijeva kriterija izražena kroz uporabu $d_{15}$ zrnatog filtra. To je vjerojatno zato jer je $d_{15}$ zrnatog materijala (bez obzira je li to filtar ili ne) povezan $s$ veličinom svojih pora. Vrijedi približna relacija [6]:

$$
\text { veličina pore } \approx \mathrm{d}_{15} / 5
$$

Veličina pore filtra karakterističnog otvora (bilo kojeg filtra) je definirana kao promjer najveće kugle koja može proći kroz filtar [6].

$\mathrm{Na}$ temelju vlastitih istraživanja i uzevši u obzir Terzaghijev kriterij zadržanja, Giroud [6] izvodi kriterij zadržanja za geotekstilne filtre. Iz tih razmatranja za geotekstile, on je unaprijedio i doradio i kriterije za filtre od nekoherentnog tla, uspostavljajući ovisnost kriterija o gustoći tla i koeficijentu jednoličnosti tla (ovdje se ne iznose detalji takvih odnosa jer se razmatraju samo geotekstili kao filtri). Gustoća tla će se iskazivati preko indeksa relativne gustoće $I_{D}$ :

$$
I_{D}=\frac{\epsilon_{\max }-e}{e_{\max }-\theta_{\min }}
$$

gdje je:

e zatečeni (prirodni) porozitet

$e_{\min }$ minimalni porozitet

$\mathrm{e}_{\max }$ maksimalni porozitet.

Minimalni i maksimalni porozitet određuju se propisanim pokusima na uzorku promatranog tla.

Koeficijent jednoličnosti definiran je kao:

$$
C_{u}=\frac{d_{60}}{d_{10}}
$$

gdje je:

$d_{60}$ promjer zrna od kojeg je $60 \%$ zrna u uzorku manje

$\mathrm{d}_{10}$ promjer zrna od kojeg je $60 \%$ zrna u uzorku manje.

$\mathrm{U}$ analizima izvedenim za razvoj jednadžbe za kriterij zadržanja, korišten je linearni koeficijent jednoličnosti umjesto koeficijenta jednoličnosti prema (6), kako bi se došlo do jednostavnih jednadžbi. Linearni koeficijent jednoličnosti je temeljen na pravcu koji blisko slijedi središnji dio granulometrijske krivulje. Linearni koeficijent $C^{\prime}$ u jednoličnosti definiran je:

$$
C_{u}^{s}=\frac{d_{60}^{s}}{d_{10}^{s}} \text { koji je jednak } \sqrt{\frac{d_{100}^{s}}{d_{0}^{s}}}
$$

Očito, pravac približavanja na slici je moguć samo ako je granulometrijska krivulja tla kontinuirana - ne nedostaju joj neke čestice u nizu (kao kod loše graduiranog tla). 
Giroud (6) je pokazao da se kriterij zadržavanja može iskazati kao:

$$
O_{F} \leq C \cdot d_{85 s}
$$

gdje je:

$\mathrm{OF}_{\mathrm{F}}$ općenito veličina otvora filtra neovisno o tipu filtra

C koeficijent koji ovisi o zbijenosti tla i koeficijentu jednolikosti.

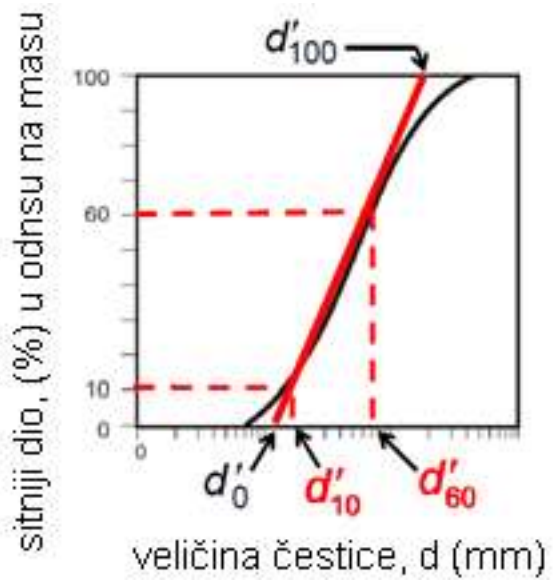

\section{Slika 12 - Linearizacija granulometrijske krivulje [6]}

Jednadžba (8) vrijedi i za geotekstile $(\mathrm{C}=1)$. Parametar $\mathrm{O}_{\mathrm{F}}$ predstavlja karakteristični otvor za geotekstile, a često se zove i drugačije, ovisno o metodi kojom se određuje $\left(\mathrm{O}_{95}, \mathrm{O}_{90}\right.$ i $A O S=$ apparent opening size $)$. Podrazumijeva se da $\mathrm{O}_{\mathrm{F}}$ predstavlja otvorenost koja je izmjerena prikladnom metodom [6].

Jednadžba (6) znači da filtar mora zadržati samo velike čestice tla. Zadržavanje samo velikih čestica funkcionira jedino ako velike čestice zadržavaju manje: drugim riječima, ako je unutarnje tlo stabilno. Stoga je Terzaghijev kriterij zadržanja nepotpun, jer ne uzima u obzir unutarnju stabilnost tla štićenog filtrom [6]. Isti autor objašnjava zašto je Terzaghijev kriterij zadržanja uspješno korišten desetljećima za konstruiranje zrnatih filtara. Prema njemu postoje dva razloga za uspješnu primjenu Terzaghijevog kriterija zadržanja u konstruiranju zrnatog filtra: a) prvi razlog je taj što zrnati filtri funkcioniraju čak i ako tlo nema unutarnju stabilnost, jer su oni debeli. Mehanizam je sljedeći: čestice koje nisu zadržane mogu se nakupljati u filtru smanjujući tako otvorenost filtra, ali filtar funkcionira; drugim riječima, zrnati filtar se može sam prilagoditi u određenom stupnju okolnom tlu, i b) drugi i važniji razlog za uspjeh Terzaghijevog kriterija zadržanja za granularni filter je taj što je njihova uporaba ograničena na najstabilnija tla, tj. tla s maksimalnom veličinom čestica uobičajeno manjom od 4,75 mm.

Giroud [6] je predložio kriterije za geotekstil za filtar, razmatrajući tkane i netkane geotekstile. Oni obuhvaćaju četiri utjecaja: poroznost geotekstila (POA - postotak pora u odnosu na površinu geotekstila, ili $A_{R}$ ), porozitet filtra $(n)$, karakteristični otvor geotekstila $\left(O_{F}\right)$ i debljinu geotekstila. Propisuju se sljedeći kriteriji:

$$
\begin{array}{ll}
\text { propusnost } & k_{F} \geq k_{S} \\
\text { karakteristični otvor } & O_{F} \leq d_{85 S} \\
\text { tkani geotekstil } & A_{R} \geq 0,1(10 \%) \text {, debljina geotekstila nema utjecaja } \\
\text { netkani geotekstil } & n \geq 0,55(55 \%) \text {, debljina ima utjecaj. }
\end{array}
$$

Za debljinu netkanog geotekstila i porozitet, Giroud [6] pokazuje da vrijedi sljedeća relacija:

$$
\frac{o_{F}}{d_{f}} \approx \frac{1}{\sqrt{1-n}}-1+\frac{10 n}{\mu G T /\left(\rho_{f} d_{f}\right)}, n=1-\frac{\mu G T}{\rho f \cdot t_{G T}}
$$

gdje je:

$\mathrm{O}_{\mathrm{F}}$ karakteristični otvor

$\mathrm{N}$ porozitet 
$\mathrm{d}_{f} \quad$ promjer vlakna geotekstila

$\mu_{G T}$ masa geotekstila po jedinici površine

$\rho_{\mathrm{f}}$ gustoća geotekstila

$t_{G T}$ debljina geotekstila.

\section{Pregled važnih kriterija za odabir geotekstila za filtar}

Inženjeri se u praksi moraju odlučiti za neki kriterij pri izboru geotekstila za filtar. Tome uvelike pomažu, ako postoje, pravilnici kojima treba udovoljiti (npr. pravilnici u obliku tehničkih uvjeta za ceste ili vodogradnju). Takav način odabira filtra zove se dimenzioniranje prema specifikacijama. Međutim, niti ti pravilnici nemaju odredbe koje su usklađene s najnovijim saznanjima. Najgora je odluka, ali ne i rijetka, da se kao kriterij za odabir geotekstila za filtar upotrijebi njegova masa. Potrebna je edukacija inženjera u tom smjeru. U ovome radu prezentiraju se relevantni kriteriji za izbor geotekstila za filtar (tablica 1). Treba napomenuti da to nisu jedini kriteriji koje treba zadovoljiti. Geotekstil treba preživjeti ugradnju i naprezanja koja dolaze iz njegove okoline: membranski efekt između zrna (relevantna je vlačna čvrstoća), pritisak zrna (relevantna je otpornost probijanjem, npr. CBR ili otpornost prodiranju šiljka i slično), oštećenja od ugradnje (relevantna je vlačna čvrstoća i otpornost na ugradnju), te otpornost na razne kemijske i biološke utjecaje. To znači da je, čak i za potrebe filtriranja, izbor geotekstila potrebno obaviti i kroz druge kriterije koji se izravno ne tiču propusnosti, nego fizičkog preživljavanja geotekstila da bi mogao obaviti funkciju filtriranja kroz životni vijek građevine u koju je ugrađen. Ta druga svojstva koja mora imati geotekstil odnose se i na funkciju odvajanja. Sva ta svojstva utvrđuju se propisanim postupcima, a potrebne vrijednosti tih svojstava propisane su raznim pravilnicima ili preporukama.

Treba primijetiti da se u mnogim kriterijima ne definiraju svi parametri koji su navedeni u tablici. Osim toga, neki kriteriji (npr. OTU, [10] i [11]) ne razlikuju jasno tkani od netkanog geotekstila, i usprkos nekim podjelama (vidi OTU za hidrotehničke zahvate [10]) kriteriji ostaju uglavnom isti. U SAD-u su vrlo razvijene specifikacije za geotekstile u prometnicama pa projektantima nije teško odabrati potreban tip geotekstila za projektne potrebe.

Poseban problem predstavlja primjena filtara u odlagalištima otpada, u temeljnom brtvenom sloju, gdje postoji mogućnost blokiranja i začepljenja filtra nanosom filtrata. Tu pojavu izazivaju sitne čestice, ali i bakterije i gljivice čija gnijezda mogu značajno umanjiti propusnost filtra. To se u određenoj mjeri događa i u prirodnim filtrima (pijesak, šljunak) i u geotekstilu. Rowe [16] razmatra taj problem i predlaže kriterije prema Giroud [17], da se koristi tkani geotekstil s AOS $=0,5 \mathrm{~mm}$ i POA $\geq 15 \%$ (bolje POA $\geq 30 \%$ ).

U Europi se preferira netkani geotekstil u odlagalištima otpada ([14]), vidi tablicu 1. Osim toga, geotekstil (koji se postavlja iznad drenažnog sloja od krupnog šljunka, a ispod otpada) može biti oštećen tjekom postavljanja (mehaničko oštećenje, djelovanje sunca), pa se predlaže da se između otpada i geotekstila stavi sloj srednjeg do krupnog pijeska koji će pokriti i sačuvati filtar od oštećenja i time od umanjenja njegove funkcije filtriranja. Postoje preporuke da se i kod željeznica stavlja posteljica od pijeska (oko $15 \mathrm{~cm}$ debljine) ispod geotekstila kada se koristi kao filtar na temeljnom tlu. 
Pregled kriterija za izbor geotekstila za filtar

Tablica 1 - Prikaz raznih kriterija za izbor geotekstila za filtar [15]

\begin{tabular}{|c|c|c|c|c|c|c|c|c|c|c|}
\hline svojstvo & \multicolumn{3}{|c|}{$\begin{array}{l}\text { HRVATSKE VODE } \\
\text { OTU [10] }\end{array}$} & $\begin{array}{l}\text { HRVATS } \\
\text { KE } \\
\text { CESTE } \\
\text { OTU [11] }\end{array}$ & $\begin{array}{l}\text { GIROUD } \\
{[6]}\end{array}$ & \multicolumn{3}{|c|}{$\begin{array}{c}\text { KÖRNER } \\
\text { [9] }\end{array}$} & \multicolumn{2}{|c|}{$\begin{array}{l}\text { BAM advisory board } \\
\text { of landfill experts } \\
\text { \& DVWK 306, } \\
\text { Saathoff i dr. } \\
{[12,13,14]}\end{array}$} \\
\hline \multirow{7}{*}{$\begin{array}{l}O_{x} \\
(m m)\end{array}$} & \multirow{2}{*}{$\begin{array}{l}\text { Područje } \\
\text { zahtjeva } 1 \\
\text { (veliki } \\
\text { karakt. } \\
\text { otvori) }\end{array}$} & \multirow{2}{*}{\multicolumn{2}{|c|}{$\begin{array}{l}\text { Područje zahtjeva } 2 \\
\text { (mali karakt. otvori) }\end{array}$}} & \multirow{7}{*}{$\begin{array}{l}0.1 \leq O_{90} \\
\leq 0.2\end{array}$} & \multirow{7}{*}{$O_{95 F} \leq d_{855}$} & \multicolumn{3}{|c|}{$\begin{array}{lll}\begin{array}{l}\text { Postotak } \\
\text { kroz }\end{array} \text { koji } & \text { prolazi } \\
(0.075 \mathrm{~mm}) & \text { No. } & \\
\end{array}$} & \multirow{7}{*}{\multicolumn{2}{|c|}{ 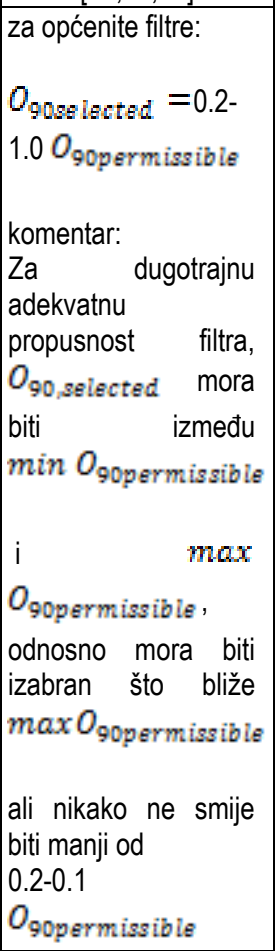 }} \\
\hline & & & & & & $\begin{array}{l}<15 \\
\%\end{array}$ & $\begin{array}{l}15-50 \\
\%\end{array}$ & $\begin{array}{l}>50 \\
\%\end{array}$ & & \\
\hline & \multirow{5}{*}{$\begin{array}{l}O_{90} \leq d_{95} \\
O_{90} \geq 0.05 \\
\text { Dodatni } \\
\text { uvjet za } \\
\text { zaglinjeni } \\
\text { šljunak: } \\
O_{90} \geq 4 d_{1 \neq}\end{array}$} & $d_{50} \leq 0.06$ & $d_{50}>0.06$ & & & \multirow{4}{*}{ 焉 } & \multirow{4}{*}{ 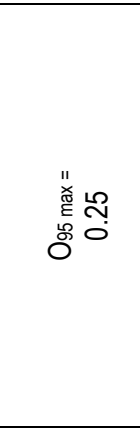 } & \multirow{4}{*}{ 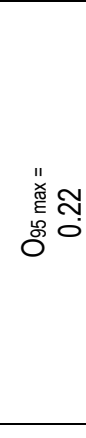 } & & \\
\hline & & \multirow{4}{*}{\multicolumn{2}{|c|}{ 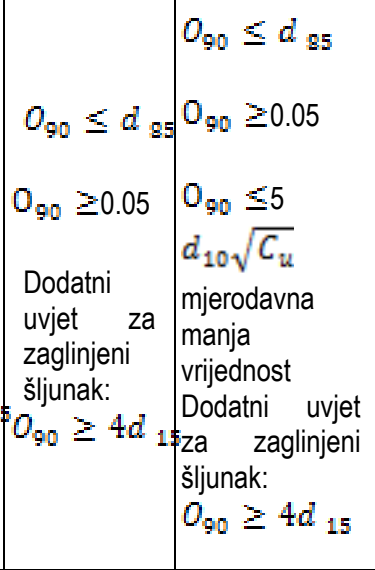 }} & & & & & & & \\
\hline & & & & & & & & & & \\
\hline & & & & & & & & & & \\
\hline & & & & & & \multicolumn{3}{|c|}{$o_{95} \leq(2-3) d_{85}$} & & \\
\hline $\begin{array}{l}\mathrm{kG} \\
(\mathrm{m} / \mathrm{s})\end{array}$ & \multicolumn{3}{|c|}{$\begin{array}{l}k_{G} \geq(10-100) k_{g} \\
10 \text { se može uzeti kod relativno malog } \\
\text { protoka, načelno treba uzimati gornju } \\
\text { vrijednost: } 100 \mathrm{ks}\end{array}$} & $\begin{array}{l}k_{v} \geq 1 \times 10^{-} \\
3\end{array}$ & $\begin{array}{l}k_{G} \geq i_{g} k_{g} \\
k_{G} \geq k_{g}\end{array}$ & \multicolumn{3}{|c|}{$k_{G} \geq k_{g}$} & & \\
\hline $\begin{array}{l}\Phi \\
\left(\mathrm{s}^{-1}\right)\end{array}$ & & & & $\begin{array}{l}>5 \\
\cdot 10^{-7}\end{array}$ & & & & & & \\
\hline $\begin{array}{l}\Psi \\
\left(\mathrm{m}^{2} / \mathrm{s}\right)\end{array}$ & & & & $\geq 1$ & & 0.5 & $\begin{array}{l}0.2 \\
5\end{array}$ & 0.22 & & \\
\hline $\begin{array}{l}\text { Porozn } \\
\text { ost } \\
(\text { POA,n, } \\
\left.A_{R}\right)\end{array}$ & & & & & $\begin{array}{l}A_{R} \geq 0.1 \\
\text { tkani } \\
\text { geotekstil } \\
\mathrm{n} \geq 0.55 \\
\text { netkani } \\
\text { geot. } \\
\end{array}$ & $\begin{array}{l}\text { POA } \geq \\
\text { geoteks } \\
n \geq \\
\text { geoteks }\end{array}$ & 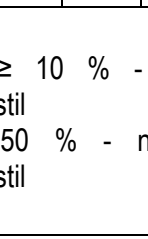 & $\begin{array}{l}\text { tkani } \\
\text { tetkani }\end{array}$ & & \\
\hline $\mathrm{d}(\mathrm{mm})$ & & & & - & & & & & $\begin{array}{l}\mathrm{d}_{\min } \geq 3 \\
\mathrm{~mm}, \\
\mathrm{~d}_{\min } \geq \\
30 \mathrm{O}_{90}\end{array}$ & \\
\hline $\begin{array}{l}\text { Masa } \\
\text { po } \\
\text { jedinici } \\
\text { površin } \\
\text { e } \\
\end{array}$ & & & & - & & & & & $\begin{array}{l}\text { Minimal } \\
\text { no } \\
300 \\
\mathrm{~g} / \mathrm{m}^{2}\end{array}$ & $\begin{array}{l}\text { za } \\
\text { odlagališ } \\
\text { ta } \\
\text { otpada }\end{array}$ \\
\hline $\begin{array}{l}\text { CBR } \\
(\mathrm{kN})\end{array}$ & & & & $\begin{array}{l}\geq \\
1 ; 1,1,5 ; 1,8 \\
\text { ovisi o tlu }\end{array}$ & & & & & $\begin{array}{l}\text { Min. sila } \\
2.5 \mathrm{kN} \\
\text { min } \\
\text { deform. } \\
50 \mathrm{~mm}\end{array}$ & \\
\hline
\end{tabular}

Perić, N; Mulabdić, M 
gdje je:

Područje zahtjeva 1 = tlo može samo stvoriti filtar u sebi

Područje zahtjeva 2 = tlo ne može samo stvoriti filtar u sebi

$\mathrm{k}_{G}=$ koeficijent propusnosti geotekstila; $\mathrm{k}_{\mathrm{S}}=$ koeficijent propusnosti tla; $\mathrm{POA}=$ percent opening area (poroznost površine promatrana kroz prodor svjetlosti); $A_{R}=$ POA prema Giroudu za tkani geotekstil; $n=$ poroznost netkanog geotekstila prema Giroudu; $\Phi=$ permitivnost (okomito na ravninu); $\Psi=$ transmisivnost (u ravnini); $d=$ debljina geotekstila pod opterećenjem ; $\min \mathrm{O}_{90}$ permissible $=$ odnosi se na sprječavanje zapunjavanja filtera; $\max \mathrm{O}_{90}$ permissible $=$ odnosi se na sprječavanje erozije [13].

\section{Napomena:}

Treba primijetiti i objasniti razliku u oznakama svojstva geotekstila iskazanu parametrom $\mathrm{O}_{90} \mathrm{i} \mathrm{O}_{95}$. Obje se oznake odnose na karakterističnu veličinu otvora geotekstila (AOS). O90 odnosi se na metodu mjerenja EN ISO 12956 prema kojoj se provodi sijanje nekoherentnog tla propisanih svojstava kroz geotekstil, sve dok se ne postigne da prolaz tla kroz uzorak geotekstila bude manji od $10 \%$. O95 se odnosi na normu ASTM D4751 koja propisuje da se staklene kuglice različith promjera prosijavaju kroz geotekstil tako da prođe $5 \%$ mase svih kuglica, pa onda taj promjer kuglica predstavlja vrijednost $\mathrm{O}_{95}$.

\section{Primjer zahtijevanih kriterija za izbor geotekstila za filtar}

U praksi je potrebno detaljno opisati kriterije za odabir geotekstila za filtar, sa svim potrebnim parametrima i njihovim vrijednostima, kako bi se smanjili nesporazumi i osigurao učinkovit geotekstil. Ovdje će se navesti dva primjera za izbor geotekstila - za cestu i za odlagalište otpada.

\subsection{Odabir geotekstila za prometnicu}

U prometnicama se geotekstil pojavljuje najčešće i kao filtar i kao sloj za odvajanje, pa stoga treba propisati i njegova mehanička svojstva i pritom voditi računa o sljedećem:

- $\quad$ karakter podloge - mekša podloga je najčešće vezana za sitne čestice pa zahtijeva veću istezljivost, nižu vrijednost $\mathrm{O}_{90}$ (manja vrijednost za veći sadržaj sitnih čestica) i veću vlačnu čvrstoću; ako postoje i krupnija zrna u podlozi (ili kamenje), potrebno je povećati debljinu geotekstila ili postaviti podlogu od pijeska; za izbor geotekstila je važniji granulometrijski sastav temeljnog tla na koji se on polaže nego čvrstoća temeljnog tla (često iskazana parametrom CBR);

- režim podzemne vode - ako se očekuje pojava vode u ravnini geotekstila, treba osigurati veću propusnost okomito na ravninu (permitivnost), koja mora biti nešto veća od propusnosti tla ispod geotekstila (iz kojeg dolazi voda);

- karakter nasipnog materijala koji se polaže na geotekstil - krupnija i uglata zrna zahtijevaju bolja mehanička svojstva, a to znači veću vlačnu čvrstoću, veću otpornost na probijanje, veću debljinu;

- kada se koristi netkani geotekstil, potrebna je odgovarajuća debljina - zbog uvjeta propusnosti i zbog zaštite od pritiska zrna.

Primjer odabira netkanog geotekstila za filtriranje u prometnicama:

Netkani geotekstil, $\mathrm{O}_{90} \leq 0.2 \mathrm{~mm}$ (neki stručnjaci predlažu i do pet puta manji $\mathrm{O}_{90}$ za prašinasto-glinovite materijale), propusnost okomito na ravninu $\mathrm{k}_{\mathrm{v}} \geq 1 \times 10^{-3} \mathrm{~m} / \mathrm{s}$, propusnost u ravnini veća od $5 \times 10^{-7} \mathrm{~m} / \mathrm{s}, \mathrm{CBR}$ veći od $3 \mathrm{kN}$, vlačna čvrstoća od $15 \mathrm{kN} / \mathrm{m}$ u oba smjera, istezanje pri toj čvrstoći barem $50 \%$, debljina geotekstila barem $4 \mathrm{~mm}$, biološka i kemijska otpornost.

\subsection{Odabir geotekstila za odlagalište otpada}

Puno je kompliciranije i teže formirati kriterije za filtar za odlagalište otpada u temeljnom sustavu. Tu se misli na geotekstil između otpada i drenažnog sloja temeljnog sustava. U odlagalištima otpada je dodatna prijetnja geotekstilu (filtru) zapunjavanje vlaknima iz filtrata, te stvaranje gnijezda od gljivica i bakterija koja mogu blokirati filtar. Geotekstil treba imati mehanička svojstva da izdrži tlakove od nadsloja koje treba savladati kroz otpornost na probijanje, na istezanje, na agresivnost filtrata i na membranske efekte. Često se iznad geotekstila stavlja sloj pijeska kao tampon-zona prema otpadu. Može se koristiti tkani i netkani geotekstil, pa se za takav geotekstil može tražiti da zadovolji sljedeće: 
a) tkani geotekstil, CBR veći od $3 \mathrm{kN}$, izduženje veće od $15 \%$ (u oba smjera), vlačna čvrstoća veća od 10 $\mathrm{kN} / \mathrm{m}^{\prime}$ (u oba smjera), propusnost okomito na ravninu bolja od $10 \mathrm{I} / \mathrm{m}^{2} / \mathrm{s}$, UV otpornost, kemijska otpornost, biodegradirajuće otporan, polipropilenska vlakna, prema kriterijima korištenim u SAD-u, geotekstil treba imati POA $\geq 30 \%$ (površina otvora kroz koje prolazi svjetlo pri osvjetljavanju geotekstila prema ukupnoj površini);

b) prema [12], od geotekstila za filtar u odlagalištu se zahtijeva sljedeće (potrebno je provesti analizu kroz više kriterija, vidi [14]).

Netkani geotekstil, masa $\geq 300 \mathrm{~g} / \mathrm{m}^{2}$, debljina min $3 \mathrm{~mm}$, odnosno min $30 \times \mathrm{O}_{90}, \mathrm{CBR} \geq 2,5 \mathrm{kN}$, izduženje veće od $50 \%$. Ovo su minimalni kriteriji, njima treba dodati kriterije kemijske i biodegradirajuće otpornosti.

\section{Zaključak}

Pregled postojećih kriterija za izbor geotekstila za filtar u geotehničkim i hidrotehničkim zahvatima, napravljen na temelju analize postojeće literature i pravilnika, pokazuje da je taj izbor potrebno obaviti vodeći računa 0 vrsti zahvata, vrsti tla i uvjetima okoliša. Kriteriji su različiti za tkani i netkani geotekstil, a obuhvaćaju poroznost, karakteristični otvor, debljinu i propusnost geotekstila. Uz ove kriterije potrebno je propisati i kriterije za mehanička svojstva geotekstila. Kod primjene geotekstila u odlagalištima ispod otpada preporučena je zaštita slojem pijeska. Bez razumijevanja razloga za uvođenje pojedinog kriterija, često nije moguće ispravno odrediti sve parametre za ispravan izbor geotekstila za filtar. Postojeće preporuke i specifikacije mogu poslužiti kao vodič za izbor geotekstila, ali za složenije i zahtjevnije uvjete potrebno je provesti analizu različitih kriterija i tako dimenzionirati svojstva geotekstila.

\section{Literatura}

[1] HRN EN ISO 10318:2008. 2008. Geosintetici - Nazivi i definicije (ISO 10318:2005; EN ISO 10318:2005)

[2] Mulabdić, M., Bošnjaković, M. 2011. Pojmovnik geosintetika, Izdavač Građevinski fakultet Osijek, pp 143

[3] IGS Mini Lectures - 2002

[4] Nonveiler, E. (1987). Nasute brane, Školska knjiga, Zagreb, pp 348

[5] www.geosyntheticsmagazine.com

[6] Giroud, J.P. 2010. Development of criteria for geotextile and granular filters, 9th International Conference on Geosynthetics, Brazil, pp 45-64

[7] Watson P.D.J., John N.W.M.1999: Geotextile filter design and simulated bridge formation at the soilgeotextile interface. Geotextiles and Geomembranes, Vol.17,pp.265-280

[8] Moraci, N. 2010. Geotextile filter: Design, characterization and factors affecting clogging and blinding limit states, 9th International Conference on Geosynthetics, Brazil, pp 413-435

[9] Körner, R.M. 2005. Designing with Geosynthetics, Pearson Prentice Hall, 5th edition, pp 796

[10] OTU, 2010. Opći tehnički uvjeti za radove u vodnom gospodarstvu - Hrvatske vode, knjiga 1, str. 55

[11] OTU, 2001. Opći tehnički uvjeti za radove na cestama, Knjiga 2, Hrvatske ceste-Hrvatske , str. 156

[12] BAM. Richtlinie für die Zulassung von Kunststoff Dränelementen für Deponieoberflächenab dichtungen. BAM Bundesanstalt fiir Materialforschung und - prüfung, 2010

[13] DVWK 306. Guidelines for water management 306 (1993): Application of geotextiles in hydraulic engineering. (Ed. German Association for Water Resourcesa and Land Improvement) QI SBN 3- 922671 $41-1$

[14] Saathoff, F., Cantré, St., Müller, W. 2010. The new German filtration criteria for geosynthetics in landfills, $5^{\text {th }}$ European Geosynthetics Congress, Valencia, pp 264-268

[15] Peric, N. 2013. Geosintetici u funkciji filtara i drenaža, Građevinski fakultet Sveučilišta JJS u Osijeku, završni rad na preddiplomskom studiju, pp 61

[16] Rowe , R.K..2005. Long term performance of contaminant barrier systems, Geotechnique 55, No 9, pp 631678

[17] Giroud, J.P., 1996, "Granular Filters and Geotextile Filters", Proceedings of GeoFilters '96, Lafleur, J. and Rollin, A.L., Editors, Montréal, Canada, May 1996, pp. 565 - 680 